The Serials Librarian, 2008. Vol. 54, No. 1-2, p127-134.

doi: 10.1080/03615260801973935

ISSN: 0361-526X (Print), 1541-1095 (Online)

http://www.tandfonline.com/

http://www.tandfonline.com/toc/wser20/current

http://www.tandfonline.com/doi/abs/10.1080/03615260801973935

http://dx.doi.org/10.1080/03615260801973935

(C) 2008 The Haworth Press.

\title{
From Tech Services to Leadership
}

\author{
Anne McKee \\ Moderator \\ Joyce Ogburn \\ Carol Pitts Diedrichs \\ Karen Calhoun \\ Panelists
}

Sarah E. Morris

Recorder

\begin{abstract}
The panel at this strategy session was composed of three distinguished women from technical services who currently hold leadership positions. The session topic was divided into two sections: 1) What is leadership?; and 2) How can technical services help you be a leader? Each panelist spoke to the first topic and then reversed order to explore the second. The panelists all spoke to a definition of leadership based on the personal, social, and professional skills possessed by leaders. The panel concurred that technical services staff are uniquely prepared for leadership for a variety of reasons because the personal, social, and professional skills discussed by the panel in the first half of the session are prevalent in technical services departments.
\end{abstract}

\section{INTRODUCTION}

If the full crowd at NASIG 2007 was any indication, technical services and leadership remains a timely topic. The panel at this strategy session was composed of three distinguished women from technical services who currently hold leadership positions: Joyce Ogburn, University Librarian at the University of Utah; Carol Pitts Diedrichs, Dean of Libraries and William T. Young Endowed Chair at the University of Kentucky; and Karen Calhoun, Vice President, OCLC WorldCat and Metadata Services at OCLC Online Computer Library Center. The moderator was Anne McKee, Program Officer at the Greater Western Library Alliance.

The session topic was divided into two sections: 1) What is leadership?; and 2) How can technical services help you be a leader? Each panelist spoke to the first topic and then reversed order to explore the second. This report will cover both halves, focusing first on the common 
threads discussed by all three panelists and concluding with the question and answer period.

\section{PART ONE: WHAT IS LEADERSHIP?}

The panelists all spoke to a definition of leadership based on the personal, social, and professional skills possessed by leaders. Their list of personal principles was not surprising: courage, honesty, integrity, fairness, tact, patience, passion, energy, optimism, and flexibility. Carol Pitts Diedrichs emphasized the works of Daniel Goleman, an internationally known psychologist, on the importance of emotional intelligence in the workplace. Having the emotional intelligence skills to be both self-aware and self-regulated and personal emotional skills such as being emotionally stable or "centered" are important. Additional personal skills needed by leaders focused more on their relationship to their work: to have clarity of vision, perseverance, a restlessness with the status quo, an orientation toward the future, a pursuit of opportunities, lots of questions, and a need to do your best. None of the panelists left out the importance of having a sense of humor and a desire to have fun while pursuing your dreams.

The personal skills developed by practiced leaders are important, but the panelists focused just as much on these elements as on the way leaders relate to others and, most especially, to those who follow them. Joyce Ogburn noted in particular that leadership involves both the process and the people. The social skills the panelists noted included being a good listener, being respectful, having, and showing empathy, learning the art of persuasion, being able to find common ground among varied parties, and having influence as opposed to power. Because leadership depends on followers, the panelists emphasized working in a team and remembering that no one is a leader by him or herself.

The panelists also spoke to the leadership characteristics displayed professionally, stemming from personal and social skills that combine in the workplace to produce particular traits. These included being able to take responsibility (for yourself and your work), to manage conflict rather than avoid it, to have a strong commitment to your organization, to build coalitions, and to stay informed and connected.

Joyce focused on what stops people from being leaders. To go from "I can't" or "This won't work" to "I can do it," Joyce recommended starting small. For example, consider the future. Rather than be afraid of it, think about where you would really like to be. While initially it may look too big to handle, breaking the process down into manageable parts can make it easy to get started and really make a difference in achieving your goals. Look where you are and what you can do, even if it's a small thing, and you will be amazed at how quickly you can move forward.

Carol focused on the social aspect of leadership, those other people so necessary to its practice. Carol's advice was to remember that, "it's not all about me." Focusing on those who are being led is difficult because you need to listen to all the voices, especially the dissident ones, while remembering to be civil and respectful. This means you may have to adjust your style to deal with a myriad of personalities. While doing so, you must take the feelings of your followers into account, which requires more effort. The more you lead, Carol noted, the more you will appreciate great followers. She offered some tips to bring followers together, including working with the assumption that nothing important is done alone (no leader is an island).

Using the concept of the movie, Pay It Forward, Karen Calhoun reminded us that leadership is thinking about what will make the world better and what we can do about it. Building on the inspiration of Elizabeth Cady Stanton and civil rights leaders of the $20^{\text {th }}$ century, Karen emphasized taking small steps and persevering through the messy process of leadership. Once you 
are willing to be the first one to go forward, you have to communicate your vision and seek to influence others, not to command them. Expanding on Carol's comments, Karen emphasized having respect for others: listening and understanding the other person's perspective, and knowing what they want. Karen also discussed Ned Herrman's Brain Dominance model, noting that technical services staff members tend to self-select for the limbic-left model (organizers), but we should instead seek to use our whole brain and incorporate the other types (theorists, humanists, and innovators), regardless of our preferences and tendencies, in order to be successful leaders.

\section{PART TWO: WHAT IS TECHNICAL SERVICES' CONTRIBUTION TO LEADERSHIP?}

In the second half of the strategy session, the panelists turned to the topic of how experience in technical services can help you be a leader. The panel concurred that technical services staff are uniquely prepared for leadership for a variety of reasons. Those personal, social, and professional skills discussed by the panel in the first half of the session are prevalent in technical services departments.

Karen started this section by remarking that technical services departments have been so squeezed for staff and resources over the last twenty years that necessity has become the mother of invention. All the panelists agreed that such an environment prepared them well by reinforcing leadership skills. By managing people and resources, adhering to a code of ethics and accountability standards, applying new technologies, working as part of a team, dealing with constant change, and serving customers - all while cultivating an environment ripe for innovation-technical services staff members hone their leadership skills on a daily basis at all levels, not just that of senior management.

In stressing the importance of the people you work with, Karen commented that people are the softest of software and that social skills are essential to ensure that the work is done. The interesting part, she noted, is that technical services departments tend to draw the most interesting personalities, creating an excellent opportunity to apply the whole brain model.

Carol remarked that technical services enable you to become a leader because the environment allows you to pick up the skills faster. Especially for those with acquisitions experience, you really "get" budgets and have a practiced ability to make the money work out. Aside from the money, technical services departments understand serving internal customers and dealing with happy and unhappy people, stressing the importance of practicing and developing these skills through organized training, although such opportunities must often be sought out.

To close up the second half of the presentation, Joyce gave some concrete examples of leadership from technical services. On the cataloging side, there is the MARC record, early library automation efforts such as the old OCLC Beehive terminals, online catalogs and of course, OCLC. In terms of technology, technical services has been automated for many years, is accustomed to using online integrated library systems, and more recently added electronic resource management systems, digitization and digital library development to its portfolio. Technical services have been in the forefront of standards development and adoption, as evidenced by EDI (electronic data interchange), DOI (digital object identifier), MARC 21, Serial Item and Contribution Identifier NISO Z39.56, Holdings statement NISO Z39.71, and many others. Technical services has also shown professional leadership in metadata, process improvement and efficiency, dealing with the serial pricing crisis, changes in scholarly communication, and essential disaster planning and recovery. Finally, Joyce noted that the hallmark of technical services is collaboration-sharing 
resources and simply "sharing the load."

In each of their final remarks, the panelists noted some "tips of the trade" for leaders. Karen noted that patience is important to try to learn, even though leaders tend to be impatient people by nature. She reminded the audience that everyone could be a leader. The most important thing to do, though, is "pay it forward."

Carol offered three specific pieces of advice. First, as you rise higher in an organization you will have fewer peers inside your organization, so it is important to cultivate peers outside of your organization to serve as mentors, sounding boards, or objective listeners. Mentors, both formal and informal, are also crucial, and may reappear over the course of your career. Lastly, while transparency and open communication is important, sometimes you have to keep information confidential. Carol suggested saying "I can't talk about that (yet)," in those situations so that peers and followers will not feel as though you are deliberately withholding important information.

Joyce suggested keeping a "feel good file" where you can save a record of positive feedback you receive that may inspire or reinvigorate you and help you survive difficult periods in your career. Technical services tends to receive fewer thanks or positive comments than a more visible public services department, and there may be even less acknowledgement as you rise to the top of an organization, when the appreciation appropriately goes to those on the front line who are doing the work. Reminding us to lead from the middle, Joyce cautioned against running too far ahead and losing those behind you and leading from the rear while nipping at the heels of those in front of you. She also noted that a "can do" attitude really pays off. In terms of professional development, she recommended reading contemporary business literature to glean leadership lessons from great business leaders, but also exploring other aspects of leadership, such as leadership for the common good. A list of the panel's recommended reading is included at the end of this report.

\section{Question \& Answer Section}

To close out the session, the panelists held a question and answer section, fielding as many questions from their lively audience as time allowed. The first question asked how to successfully build coalitions, as the audience member had had a bad experience doing so. The panel's consensus was that you need to start by building relationships. You need to get out of your office so that you know the players and they know you, because once those relationships are built the collaboration comes more easily. They suggested to first approach those who are likely to agree with you, and that will build momentum for others to follow. However, they also pointed out that some people will never buy in, which is okay.

The second question was whether we are preparing staff members to lead in our departments and organizations - whether we are building success in the institution itself. Sometimes promotions come to those who are best at a particular task, not necessarily to those who are the best leaders. The presenters noted that the Association for Research Libraries (ARL) has many leadership development programs as do other institutions, and they recommended attending as many formal programs as interest, aptitude, time, and money allow.

The next questioner observed that many senior managers seemed to spend an inordinate amount of time on work so asked for advice on how to achieve a work/life balance. The panel agreed that sacrifices need to be made, especially at the top level, but you make your own choices about what sacrifices you are willing to make. However, as your life changes and subsequently your priorities, the blend of work/life balance changes, too. Balance is a very personal issue that 
will be with you throughout your career. Because leadership can happen at every level, you do not always have to be at the top to be a leader. It may be easier to achieve the balance you desire from a lower position in the organization. The panel suggested consciously developing leadership skills of more staff to relieve some of the pressure of being at the top of the organization chart. Carol also made a plea to everyone to let your Dean have some balance, too!

The fourth question dealt with generational differences, a topic that came up in several other sessions during the conference. All of the panelists agreed that generational differences are very situational. You need to be aware of and appreciate what you don't know and how American cultural mores impact the workplace. Libraries often have a very international workforce with different ideas about how the workplace should work. Sometimes other issues can masquerade as generational differences. The panel also reminded the audience that you are not your mentor and your perspective will change as your stage in life changes. In terms of leadership, they suspect that a new definition of leadership will come as a new generation moves into the top positions.

With only a few minutes left in the session, the last audience question was how the panelists had learned to accept help from support staff since secretaries and administrative assistants in technical services are a rare commodity. The panel all had varying experiences with and without assigned support staff, but noted that you really will live or die by support staff. Joyce noted that it is a process of learning how to use help, and how much they really can help you, but in the end, it's worth it. Going back to those original personal skills mentioned earlier, flexibility is pivotal because it's a give and take situation and delegation is key. You need to have time to do your job and you need to let your support person help you. Carol recommended using technology, such as synchronized PDAs as a tool, and to ask for the tools you need to do your job.

From Tech Services to Leadership was a well-attended session, which sparked discussion in other sessions during the rest of the conference. This attributed to the quality and timeliness of its advice. No doubt, future NASIG leaders will reference this presentation as a catalyst for their success.

\section{RECOMMENDED READING}

1. Block, P. (2000). Flawless Consulting: A Guide to Getting Your Expertise Used. San Francisco: Jossey-Bass/Pfeiffer.

2. Bridges, W. (1991). Managing Transitions: Making the Most of Change. Reading, MA: Addison-Wesley.

3. Crosby, B. C., \& Bryson, J. M. (2004). Ed. Goethals, G. R., G. J. Sorenson, \& J. M. Burns. Leadership for the Common Good. In Encyclopedia of Leadership. Thousand Oaks, CA: Sage.

4. Diedrichs, C. P. (1998). Rethinking and Transforming Acquisitions: The Acquisitions Librarian's Perspective. Library Resources \& Technical Services, 42 (2), 113-125.

5. Goleman, D. (1995). Emotional Intelligence. New York: Bantam Books.

6. Goleman, D., Boyatis, R. E., \& McKee, A. (2002). Primal Leadership: Realizing the Power of Emotional Intelligence. Boston, MA: Harvard Business School Press.

7. Goethals, G. R., Sorenson, G., \& Burns, J. M., Eds. (2004). Encyclopedia of Leadership. Thousand Oaks, CA: Sage Publications.

8. Gregor, D., \& Mandel, C. (1991). Cataloging Must Change! Library Journal, 116(6), 4247.

9. Herrman, N. (1989). The Creative Brain. Lake Lure, NC: Brain Books. 
10. Lakos, A., \& Phipps, S. (2004). Creating a Culture of Assessment: A Catalyst for Organization Change. Portal: Libraries and the Academy 4, (3), 345-361.

11. Mitchell, M., Ed. (2007). Library Workflow Redesign: Six Case Studies. Washington, D.C.: Council on Library and Information Resources.

12. Patterson, K. (2002). Crucial Conversations: Tools for Talking When Stakes are High. New York: McGraw-Hill.

13. Von Oech, R. (1983). A Whack on the Side of the Head: How to Unlock Your Mind for Innovation. New York: Warner Books. 